\title{
KRAETPATIENTERS BRUG AF REIKI-HEALING SOM MAGISK PRAKSIS
}

\author{
HANNE BESS BOELSBJERG
}

\begin{abstract}
Normalt foregår healingen ligesom i dag: Jeg ligger ned, og min healer siger ikke noget før bagefter, hvis hun har oplevet et eller andet specielt. Men her sidste gang gik der ikke mere end, ja, få øjeblikke, så tog hun det lommetørklæde, der lå hen over øjnene, af mig, og så sagde hun: 'Jeg bliver altså nødt til at sige det til dig nu!' Jeg kunne høre, hun var begejstret, og jeg tænkte, hvad sker der? Hun havde set, at der var et spirende træ et eller andet sted på min krop, hvor hun healede mig. Det var hun så glad for, for det var et tegn på, at det ville give mig mere liv og mere energi [...] Måden, hun fortalte det på, og hele stemningen gjorde, at jeg egentlig blev enormt positiv og tænkte: 'Yes! Så hjælper det!' Så er der et eller andet beviseligt på, at det her er godt, ikke?
\end{abstract}

Brugen af alternative behandlingsformer er generelt stigende i Danmark og andre vestlige lande (Ahlin 2007; Eisenberger et al. 1998). Blandt kræftpatienter anvender næsten halvdelen en eller flere alternative behandlingsformer sideløbende med den konventionelle behandling (Damkier 2000). Det er specielt kosttilskud og kostændringer, der præger billedet, i samspil med zoneterapi, akupunktur og biopati. Reiki-healing er et af de behandlingstilbud, der anvendes, om end i mindre udstrækning. Reiki-healing kan ifølge behandlernes udsagn styrke personens energisystem og ad den vej lindre de fysiske eller psykiske problemer, som har fået personen til at opsøge healeren. Det sker efter sigende via en energioverførsel, som reiki-healeren stiller sig til rådighed for (Doi 2003). Ad den vej trækker både healeren og til en vis grad den person, der bliver behandlet, på en spirituel forståelse af mennesket, der indebærer en meget anderledes opfattelse af sammenhænge end den, der er til stede i det biomedicinske behandlingssystem.

Men de fleste kræftpatienter, der benytter sig af alternativ behandling, modtager samtidig enten strålebehandlinger eller kemoterapi. Derfor bliver de nødt til at forholde sig til to vidt forskellige sygdomsforståelser eller virkelighedsopfattelser. De kræftramte, der opsøger reiki-healing, bliver således præsenteret for 
en sygdomsforståelse, hvor deres følelser og tanker påvirker kroppens tilstand. Derigennem kan bestemte hændelser i tilværelsen anses som den dybereliggende årsag til, at de har fået kræft. Brugen af en behandlingsform, der trækker på ikkelogiske forklaringsmodeller og spirituelle årsagssammenhænge, bliver her i artiklen anskuet som en form for magisk praksis. Det står i relation til, at flere af de kræftramte, der opsøger reiki-healing, ikke trækker på den samme virkelighedsforståelse som healeren.

Hermed kan der opstå en konflikt mellem den virkelighedsforståelse, man primært orienterer sig efter (f.eks. en naturvidenskabelig), og at man vælger en behandlingsform, der beskriver menneskekroppen ud fra forskellige energibaner og -legemer, som betegnes chakraer, meridianer og aura (Ahlin 2007:29). Denne konflikt mellem at forstå sin sygdom ud fra et biomedicinsk paradigme og at tillade eller at sandsynliggøre, at den reiki-behandling, man nu har opsøgt, har en indvirkning, illustreres ved det indledende citat. Udtalelsen er fra en af deltagerne i forskningsprojektet „Kræftpatienters oplevelser af reiki-healing“, som empirien i artiklen stammer fra.

Kvinden, der her kommer til orde, er kronisk kræftpatient i begyndelsen af 50 'erne. Hun fortæller, at hun har valgt at deltage i projektet, fordi det foregår under Københavns Universitet. Hun har ikke specielt meget erfaring med alternativ behandling, men opfatter det som en form for videnskabelig garanti, at reikibehandlingen foregår i universitetets regi. Tilsammen med sit behov for lindring af de smerter og den træthed, hun døjer med, får det hende til at gå på kompromis med den naturvidenskabelige sygdomsforståelse, som hun har i kraft af sin faglige baggrund. Men det at opsøge en, for hende at se, irrationel behandlingsform bevirker, at der opstår en konflikt $\mathrm{i}$ hende mellem gerne at ville tro på, at behandlingen virker, og at bibeholde et grundlæggende naturvidenskabeligt syn på sygdom og helbredelse. Konflikten viser sig, ved at hun forsøger at berettige reiki-behandlingen ved at referere til behandlerens reaktion og udsagn som et bevis på, at det virker. Herved giver hun behandleren en særstatus som en, der udøver en bestemt (magisk) handling, der har indflydelse på hendes tilstand.

Det er et træk, som er kendetegnende ved det, der af religionssociologen Jesper Sørensen betegnes som et magisk ritual. Her tillægges bestemte elementer i ritualet en særlig kraft og betydning. Om det er en person eller en genstand, er underordnet. Det interessante er, at det er ganske særlige elementer, som deltagerne påstår er virksomme. Man refererer til dette forhold som ,,magisk agens“. Det, at noget har en magisk agens, er en nødvendig ingrediens i ritualet. For det er det element, der skaber rammen for, at ritualet potentielt set er virksomt (Sørensen 2008). I tilfældet med reiki-healing tilskriver flere af deltagerne i forskningsprojektet healeren en særlig kraft, det vil sige en magisk agens. På spørgsmålet om, 
hvordan de tror, at healing virker, svarer de fleste, at healeren har en særlig evne, som de ikke selv har. At det er healeren, der har den udslagsgivende effekt på, om behandlingen indvirker på deres tilstand eller ej.

Artiklen vil se på de måder, hvorpå kræftramte benytter sig af reiki-healing, som en magisk praksis. Det er artiklens antagelse, at reiki-healing anvendes som en magisk praksis, når den bruges af personer, der ikke tror på den virkelighed, som healeren arbejder ud fra. De giver for eksempel undvigende forklaringer som, at „der er mere mellem himmel og jord“, når der spørges ind til deres forståelse af healing. Denne holdning kan naturligvis forandre sig undervejs. Specielt når de grundet deres egne erfaringer begynder at indoptage healerens forståelse af energi som forklaring på deres kropslige oplevelser under reiki-healingen. Men som udgangspunkt er der ingen overensstemmelse mellem deres kausalitetsopfattelse eller virkelighedsforståelse og de handlinger, der foregår hos healeren. Handlingen søges berettiget ved at lave parentes omkring personens sædvanlige forståelse af tingene, for eksempel ved at referere til, at der er mere mellem himmel og jord, eller ved at henvise til, at sygdommen tvinger en til at være åben over for alternative behandlingsformer for at få hjælp.

Men artiklen ser også på brugen af reiki-healing som en måde at skabe mening med sygdommen på. For som nævnt tilbyder reiki-healing en menneskeog sygdomsforståelse, der adskiller sig væsentligt fra den, der findes inden for det etablerede sundhedssystem. Flere af deltagerne beskriver forskellen, ved at de hos reiki-healeren bliver set som hele mennesker, mens de oplever, at de mest bliver set som en diagnose på hospitalet. Det viser sig blandt andet, ved at reikihealeren tager udgangspunkt i de problemstillinger, som den kræftramte kommer med, og dermed ikke udelukkende fokuserer på symptomer og fysisk ubehag. Det kan være, at personen er meget bekymret for udsigten til at dø af $\sin$ sygdom og tænker meget på sine pårørende. Så er det dette tema, som behandleren tager afsæt $\mathrm{i}$.

Det er kendetegnende for det at blive ramt af kræft, at det i de fleste tilfælde udløser en krise, hvor personen spørger til meningen med sygdommen (Jacobsen et al. 1998). Her kan reiki-healeren medvirke til at skabe en mening med den situation, den kræftramte befinder sig i. Det sker ved at tilbyde en fortolkningsramme at forstå sygdommen ud fra (Ostenfeld-Rosenthal 2007). Reiki-healing kan på den måde støtte personen i at få et nyt perspektiv på sin livssituation og nærme sig en dybere accept af sin tilstand. Gennem det at orientere sig ud fra reiki-healing som et meningssystem kan behandlingen medvirke til en bedre håndtering af de eksistentielle udfordringer, der kan opstå i forbindelse med kriser eller ved alvorlig sygdom (Jacobsen 2000). Derved muliggør behandlingen det, der inden for religionspsykologien betegnes som religiøs coping (Pargament 2001). 
Religiøs coping anskues i artiklen som den mere fortolkende del af den magiske praksis, altså det at skabe en meningsfuld forståelse af sygdommen for at opnå en sammenhængende fortælling i personens livsforløb (Antonovsky 2000). Religiøs coping ses stadig som en del af den magiske praksis, der består i at deltage $i$ en handling, hvor et bestemt element tillægges en magisk agens. Men når brugen af reiki-healing betegnes som religiøs coping, indebærer det, at den kræftramte har en tilgang til behandlingen, der indbefatter healerens virkelighedsforståelse. Deltagerens egen måde at opfatte virkeligheden på kommer derfor til at ligge i forlængelse af det, der foregår i behandlingslokalet. Er der en sådan åben og medlevende indstilling til stede, kan healeren og den kræftramte etablere et meningsfællesskab, hvor den kræftramte oplever at modtage fysisk omsorg, få følelsesmæssig støtte og at føle anerkendelse for sine valg og sin tilværelsesforståelse. På denne måde nærmer det at modtage reiki-healing for disse personer sig en religiøs praksis, hvor der er overensstemmelse mellem ens virkelighedsforståelse og den rationalitet, der ligger bag de handlinger, man foretager sig.

\section{Kræftpatienters oplevelser af reiki-healing}

Empirien, der ligger til grund for artiklen, stammer som nævnt fra forskningsprojektet „Kræftramtes oplevelser af reiki-healing“. Formålet med undersøgelsen var at belyse deltagernes erfaringer med behandlingen, herunder hvilke sensoriske forandringer de registrerede, hvad de tillagde betydning i behandlingsforløbet, samt hvad de opfattede som virkninger afstedkommet af reiki-healingen. Hver deltager var i et behandlingsforløb over otte gange. De 15 deltagere blev fordelt mellem tre healere, der supplerede healingen med enten aromaterapi, lydhealing eller clairvoyance. De elementer, som deltagerne tillagde betydning ved behandlingen, kan derfor ikke alene tilskrives reiki-healing. Men da det inden for alternativ behandling er et udbredt fænomen at blande behandlingsteknikker, var vi indforstået med, at healerne benyttede sig af deres vante arbejdsform, og anså det som et vilkår for den måde, reiki-healing praktiseres på. Deltagerne blev interviewet fire gange undervejs, og 14 dage efter behandlingen var afsluttet. De blev desuden iagttaget under halvdelen af deres behandlinger, såvel de indledende som de afsluttende.

De oplevelser, deltagerne refererer til, spænder vidt. Der er flere, der betoner det velgørende i at få lejlighed til at slappe af fra sygdommen og opleve, at deres identitet er andet end at være patient. De fortæller, at reiki-healing er et sted, hvor de kan lade op og få energi til at håndtere det udmattende i at være $\mathrm{i}$ et behandlingsforløb med for eksempel kemoterapi. En kvinde med tarmkræft, der er i midten af 50'erne, siger: 
Når jeg har fået kemo, så er jeg blevet banket helt ned i bunden af den dybeste sorte mørke kælder, og så kan jeg have det rigtig, rigtig svært med at få kravlet lidt op ad trapperne. Med det her healing så er det ligesom om ... så bliver man lige løftet op på næste (trappe)repos, og der er trinene nemmere at gå på.

Andre beretter, at behandlingen berører dem mere eksistentielt. Disse deltagere betoner, at de gennem healingen får arbejdet med følelsesmæssige aspekter, som de selv forbinder med det at være blevet ramt af kræft. Det kan være smertefulde barndomsoplevelser eller uhensigtsmæssige adfærdsmønstre, der bliver tematiseret. Ofte er der hos deltageren en fornemmelse af at få indsigt i sig selv og sit følelsesliv, og flere betegner det som forløsende, og at de får ryddet op i ,den psykiske skraldespand“. En kvinde i slutningen af 40'erne, der er blevet opereret for brystkræft og efterfølgende har fået stråler, fortæller:

De første fem gange blev nok brugt til at rydde meget op i min rygsæk, livets rygsæk. Og siden der er blevet ryddet op igen, så synes jeg kun, at der har været meget lys for enden, og det er gået fremad, rigtig meget.

Atter andre betegner indholdet af det, de oplever, som en mere meditativ proces, hvor de ved hjælp af healeren skifter bevidsthedstilstand. En kvindelig brystkræftpatient beskriver det i sin evaluering af behandlingsforløbet:

[Healingen] gik ind på nogle andre måder end det andet (psykologen). [Det var] en anden form for støtte [...] helt klart mere fysisk og så også, jo mere jeg tænker over det, som en form for meditation faktisk, det var sådan en hjælp til det.

Samlet set har alle deltagerne haft kropslige oplevelser af varme, kulde eller det, de betegner som „energi“, og flere har sanset berøringer på kropsdele, efter at healerens hånd har flyttet sig. Mange beskriver også oplevelser af farver eller lys, følelser og erindringsbilleder. Alle deltagere siger, at det overordnet har været behageligt og for de flestes vedkommende også meget afslappende at modtage reiki-healingen. Undersøgelsens konklusion lyder, at flere af de kræftramte oplever at få forbedret deres almentilstand gennem det at modtage reiki-healing, det vil sige, at de får mere energi, sover bedre, har færre smerter. Flere oplever også det at modtage reiki-healing som en støtte til de eksistentielle udfordringer, der opstår som følge af at have fået kræft. Hvorvidt reiki-healing har en specifik indvirkning på kræftsvulstens størrelse eller udbredelse, har undersøgelsen ingen mulighed for at udtale sig om. 


\section{Reiki-healingens oprindelse og udbredelse}

Reiki-healing er en behandlingsform, som oprindelig stammer fra Japan. „Reiki“ er derfor et japansk ord, der består af to ord eller skrifttegn: „rei“ og „ki“, der betyder henholdsvis ,universel“ og „livsenergi“. „Ki“ står for det samme som det kinesiske „chi“, der dækker over en kraft, der lever og virker i alt (OstenfeldRosenthal 2005). I reiki-traditionen beskrives denne energi som en vibration af kærlighed ,udstrålet fra den højeste bevidsthed fra en eksistens i den højeste dimension" (Doi 2003:31).

Ifølge sin egen beskrivelse er reiki-healing en metode, der anvender håndspålæggelse til at heale krop, sind og ånd. Metoden er indstiftet af dr. Mikao Usui (1865-1926). Han studerede i Europa, USA og Kina, hvor han interesserede sig for medicin, psykologi og religion. Han vendte derefter hjem til Japan og begyndte at praktisere zenbuddhisme. Under en faste på bjerget Kurama blev han bevidstløs, og da han vågende op igen ,,var hans hoved fyldt med en fornemmelse af friskhed, som han aldrig havde kendt tidligere“" (Doi 2003:48). Han var blevet fyldt med energi og ,svingede dermed fuldstændigt i samklang med reiki overalt i kroppen“ (ibid.). Efter dette var han efter sigende oplyst og benyttede sine evner til at heale ved at overføre reiki-energien til andre. Hermed var reiki grundlagt som en metode til, at skabe et sundt sind og en sund krop baseret på universel reiki“" (Usui citeret fra op.cit.28). Reiki vandt stor udbredelse i Japan, og efter Mikao Usuis død videreførte hans arvtager Hawayo Takata metoden i USA, hvorfra den spredte sig til store dele af verden. I 1980'erne vendte metoden tilbage til Japan, hvor interessen for reiki genopstod og senere blev forenet med den oprindelige metode. Både den amerikanske og den moderniserede japanske retning er repræsenteret i Danmark, og i forskningsprojektet er der healere med fra begge.

Som reiki-healer er man „kanal“ for reiki-energi. Den japanske grundlægger af den moderne form for reiki-healing, Hiroshi Doi, beskriver det at være kanal som ,... at modtage vibrationen af kærlighed, i kraft af at du forener dig selv med universets bevidsthed og rytme, og at du renser dig selv, så du kan videregive vibrationen, som den er“ (Doi 2003:29). Dette lærer man gennem en indvielse fra en reiki-mester, som åbner den kanal, man transmitterer energi igennem. Rent praktisk består det af to kurser: reiki 1 og 2. Her lærer man en grundlæggende forståelse af energiarbejde, håndpositioner samt de symboler og mantraer, der anvendes under healingen (Ostenfeld-Rosenthal 2005). Herefter kan man blive reiki-mester, men det kræver et større engagement. Som reiki-mester kan man undervise og åbne andres kanal for reiki-energien. 


\section{Til behandling hos reiki-healeren}

I hvert forløb blev halvdelen af behandlingsgangene overværet, hvilket også indebar de indledende og afsluttende samtaler mellem behandler og klient. Derved bemærkede jeg, at måden at give behandling på adskilte sig en anelse mellem de tre healere og fra gang til gang. En behandler var for eksempel meget grundig i sin introduktion til healingen, hver gang der mødte en ny klient op, mens de andre forklarede det hen ad vejen. Behandlingerne varierede også på den måde, at alle tre healere havde hver deres kompetencer, som de benyttede sig af som supplement til reiki-healingen. Som nævnt blev det accepteret, at healerne kombinerede reikihealingen med andre metoder for ikke at lave om på deres behandlingsform.

Selve behandlingen påbegyndes, ved at klienten modtages ved døren. Behandlingen foregår enten i behandlerens hjem eller i en klinik, der er lyst indrettet. Der bydes på vand eller te, og man indleder samtalen med at spørge til, hvordan det er gået siden sidst, eller hvis det er første gang, hvilke symptomer eller problemer klienten kommer med.

Den healer, der benytter sig af clairvoyance, ${ }^{2}$ supplerer dette med en såkaldt kropsscanning. Hun forklarer det med, at hun sanser klientens krop gennem sin egen og mærker, hvilke områder der har behov for at blive arbejdet med. Konkret sidder hun på en stol over for klienten og starter med at lukke øjnene. Når hun er klar, åbner hun øjnene og beskriver sine fornemmelser og får dem korrigeret eller bekræftet af klienten.

Efter at have fulgt op på, hvad der er aktuelt for klienten, indledes behandlingen. Klienten lægger sig til rette oppe på briksen, og healeren indstiller sig ved hjælp af teknikkerne lært ved indvielsen, hvilket bevirker, at healeren kan ,trække reiki-energien ned i sig“. Det er ikke synligt hos alle tre behandlere. Den ene, der praktiserer den japanske form for reiki, er meget eksplicit, når hun gør det. Hun starter med at rense sig med tre strøg hen over armene og hen over brystet, hvorefter hun strækker begge arme op i vejret og trækker vejret dybt et par gange. Hos de andre to er det ikke at bemærke, da de anvender en indre praksis.

Så lægger healeren hænderne på klientens krop. Som ofte startes der ved hoved eller skulder. Selve behandlingen foregår mest i stilhed. Klienten er blevet instrueret i, at der kan komme forskellige følelser eller fornemmelser op, og at hun skal give dem plads. Hvis klienten giver sig til at græde, tørrer healeren tårerne væk med et lommetørklæde og fortsætter behandlingen. Der bliver af og til udvekslet kommentarer omkring symboler eller følelser, der dukker op under behandlingen, ellers venter man til senere.

Healeren bevæger sig hen over kroppen, oppefra og ned. Det varierer, hvor lang tid det tager - både fra behandling til behandling og mellem healerne. Den første behandling er som regel den, der varer længst tid. Den ene healer beder 
klienten om at vende sig halvvejs i behandlingen, så hun får healing på bagsiden. Healerne mener ellers, at energien løber derhen, hvor der er brug for den. En af healerne bruger de symbolske håndtegn, der fungerer som en gestus, som efter sigende forstærker en bestemt kvalitet ved energien. En anden bruger en teknik, der involverer lyd, hvilket hun mener er effektiv mod kræftcellerne i kroppen. ${ }^{3}$ To af healerne bruger desuden også visualisering i forbindelse med healing. Den ene beder klienten forestille sig sin sygdom, hvordan den ser ud, hvilken konsistens den har, og eventuelt hvad den vil fortælle. Så tjekker hun, om den forandrer sig $i$ forbindelse med behandlingsforløbet. Den anden anvender visualisering som en form for guidet meditation til at understøtte afslapning hos enkelte klienter.

Som afslutning holder healeren klientens fødder. Klienten er på det tidspunkt enten meget afslappet eller faldet i søvn, hvad der ifølge healerne er fint, fordi healingen så får lov at virke dybere. Så laves der større strøg uden om kroppen for at rense auraen eller hvirvelbevægelser nede ved fødderne. Den ene healer anvender duftterapi eller aromaterapi som del af aurarensningen. Hun vælger en flaske med en kombination af udtræk af forskellige blomster, som skal have en bestemt psykisk effekt. Når hun tager det på hænderne, medvirker det til at rense auraen for det, der er kommet op under healingen. Klienten får lov til at ligge og komme til sig selv, mens healeren går ud af rummet, vasker hænder og renser sig selv ved hjælp af mentale billeder.

Derefter fortæller begge parter om deres oplevelser under healingen. For klienten drejer det sig ofte om erindringer, følelser eller fornemmelser, mens det for healeren er symboler eller intuitive fornemmelser, der bliver refereret. Så prøver parterne at afstemme betydningsindholdet af deres oplevelser ved at diskutere, hvordan disse eventuelt passer til hinanden. Det kan for eksempel være, at healeren fornemmede en følelse af forladthed, da hun healede på skulderen, og at klienten supplerer dette med et billede, hun fik under healingen, af sin mor, der rejste bort, da hun var syv. Det kan også dreje sig om farveoplevelser, som når healeren siger, hun har lagt en masse orange ind i halschakraet, og klienten svarer, at hun havde en oplevelse af et varmt lys, der dækkede hende over brystet og op til halsen. Sådan samarbejder klient og behandler omkring at finde en fælles forståelse af healingen. Det sker naturligvis også, at det, healeren fortæller, ikke vækker genklang, og så bliver der som regel forsøgt at finde en forståelse, der imødekommer klientens opfattelse. Det kan dreje sig om, at healeren oplever, at klienten sidder fast $\mathrm{i}$ en vrede eller har en giftig grøn energi siddende $\mathrm{i}$ auraen. Billedet kan så blive omformet til en mere spiselig udgave, men hvis klienten ender med at afvise det helt, lader healeren det ligge og går videre til noget andet. På den måde er der tale om en forhandlingssituation, som også antropologen Ann Ostenfeld-Rosenthal (2007) gør opmærksom på i forbindelse med sin forskning 
i healing. Samtalen afsluttes eventuelt med en aftale om næste behandlingsgang. Der siges farvel med et håndtryk eller et knus, og klienten forlader lokalet.

\section{Reiki-healing - et helbredelsesritual}

Der er flere elementer ved en reiki-healing, der får den til at fremstå som et helbredelsesritual. Det, der betegner et helbredelsesritual, er, at det formidler en ,... helbredelse, der ikke baserer sig på fysiske eller farmakologiske behandlinger i forhold til effekt, men på sprog, ritual og manipulation af kraftfulde kulturelle symboler" (Ostenfeld-Rosenthal 2005:4). Ritualet er overordnet set en forberedt handling, der skal bevirke noget bestemt. Humphrey \& Laidlay (1994) kalder dette for ritualets arketypiske script, en slags underliggende dagsorden. Det gør det muligt at skelne mellem en rituel handling og almindelig handlen. Det særlige ved ritualet består i deltagernes indstilling til den handling, der foregår. På en måde fungerer ritualet som fastlagt og som noget, deltagerne ikke har indflydelse på. Men da det er deltagerne, der erfarer ritualet gennem krop og følelser, giver de ritualet dets betydning. Der er således et fortolkende forhold til stede mellem deltagernes intentioner med handlingen og den betydning, som ritualet tillægges (Rubow 2000:44). På den måde mener Humphrey \& Laidley, at deltagerne $i$ et ritual på den ene side fungerer som forfattere til handlingen, og at de på den anden side netop ikke gør! (Humphrey \& Laidley 1994).

Ritualer kan ligeledes være mere eller mindre ritualiserede. De mest ritualiserede er de såkaldte liturgiske ritualer, hvor former er meget fastlagt, og hvor det vigtigste er nøjagtigt at overholde de konventioner, der gør sig gældende for ritualet. De performative ritualer, hvorunder reiki-healing kan kategoriseres, er det vigtigste, ikke selve formen på ritualet. Det vil sige, at der kan improviseres med de forskellige komponenter. Men her er selve succeskriteriet for ritualet, at det virker! (Rubow 2000).

I forhold til at engagere sig i et ritual, der er performativt, eller magisk, som Jesper Sørensen ville beskrive det, er der stadig tale om, at deltagerne forventer en bestemt form for effekt (Sørensen 2008). Denne forventning er tegn på, at der er en instrumentel tankegang til stede ved at benytte sig af et magisk eller performativt ritual. Man vil med andre ord have, at det virker. Hvordan det virker, er underordnet, hvorved man kan vælge at se bort fra, at det, der foregår, ikke stemmer overens med ens egentlige virkelighedsopfattelse.

I forhold til at se på reiki-healing som et helbredelsesritual lægges der vægt på intentionen med handlingen, nemlig at den skal virke forvandlende. Det kan involvere kroppen, sindet og eventuelt det verdensbillede, man orienterer sig ud fra. Det, at et ritual kan virke forvandlende, bygger på dets iboende paradoks: 
at det kan rumme social eller kulturel orden og uorden på samme tid. Det transformerende potentiale ligger i denne sociale eller betydningsmæssig uorden. Når den kommer til udtryk, kan en ny orden etableres. Til dette formål anvender reiki-healeren flertydige symboler. Symbolerne forbinder følelser og subjektive erfaringer med kulturel mening. At de er flertydige bevirker, at der kan finde en forhandling sted mellem healer og klient, hvor de laver en fælles fortolkning af symbolerne. Den mening, de knytter til symbolerne, er forbundet med en kognitiv pol, der relaterer til erkendelse, og med en sanselig pol, der relaterer til følelser, ønsker og krop (Ostenfeld-Rosenthal 2007). På den måde er et helbredelsesritual, i dette tilfælde illustreret ved reiki-healing, en fysisk handling, der ikke kun involverer erkendelsen, men hele kroppen.

\section{Brugen af reiki-healing som en magisk praksis}

I forbindelse med forskningsprojektet kunne vi som nævnt konstatere, at alle deltagerne havde valgt at tage imod de konventionelle behandlingstilbud. Flere var sideløbende begyndt at eksperimentere med alternative behandlingstilbud, til trods for at de ikke havde anvendt alternativ behandling, før de blev syge. Men de fortalte, at de efter at have fået kræft havde følt det nødvendigt at prøve andre behandlingsformer af, fordi de håbede, at der var hjælp at hente. De følte, at de ikke havde råd til at lade være. Det er denne åbenhed for at indgå i en behandlingssammenhæng, der trækker på en anden virkelighedsforståelse end ens egen, som her i artiklen forstås som at gribe til en magisk praksis.

I det følgende eksempel illustreres brugen af reiki-healing som en magisk praksis. Heidi er studerende, og midt i 30'erne. Hun har haft meget travlt med studierne og fik efter sit udenlandsophold konstateret brystkræft. Efter diagnosen er hun startet med alternativ behandling. Ud over at melde sig til reiki-healing gennem forskningsprojektet tager hun til akupunktur og får misteltenbehandlinger. ${ }^{4}$ Hun fortæller:

Jamen, mit forhold generelt til alternativ behandling, det er sjovt, det er først nu, jeg overhovedet reflekterer over det, jeg har ikke reflekteret over det tidligere i mit liv. Der har jeg egentlig mest haft det sådan, at jeg har været meget skeptisk over for alternativ behandling. Jeg har haft det sådan, at akupunktur har jeg haft fidus til og zoneterapi i og for sig også, men ellers har jeg haft det sådan lidt, at det er noget hokuspokus. Og så læste jeg en eller anden græsrod, som havde skrevet en bog om kræft, og hvordan han ligesom sagde: 'Jeg har ikke råd til at være skeptisk! Jeg bliver nødt til at være åben', hvor hans horisont åbnede sig på en helt anden måde, ikke? 
Heidi beskriver, hvordan hun måtte overvinde sin egen skepsis og fordomme over for reiki-healing, hvilket er et træk, der optræder hos flere af informanterne. Om sine forventninger til sin første behandling siger hun:

Ja, altså det er frygteligt! Jeg har haft sådan en forestilling om, at behandleren stod og sagde mærkelige lyde og [pruster] skulle ryste den her energi ud igen, alt det der, som hun sugede til sig. Jamen, det er stort set det rene plattenslageri, det billede, jeg har haft af det!

Hendes forestilling om reiki-healing minder mest om en beskrivelse af en shaman, der fjerner onde ånder! Efter at være startet med behandlingerne forandrer hun sin opfattelse af reiki-healing. Hun begynder således at sandsynliggøre, at healingen kan have en indvirkning på hendes tilstand.

Jeg tror, det har en helbredende effekt, ikke forstået som, at det skal helbrede min sygdom. Men jeg tror, kroppen på sigt fungerer på en meget bedre måde. Altså, jeg tror mere, det kan skabe en balance eller ligevægt.

Hermed er der sket en glidende overtagelse af reiki-healerens sygdomsforståelse, hvor fokus på kroppen bliver, at den skal være i balance eller ligevægt. Det kan være, at denne stille overtagelse af en ny indstilling til krop og sygdom er et udtryk for, at magien virker! At hun har fundet en måde at beskrive på, hvad det er, hun kan bruge reiki-healing til, så hendes magiske praksis kan siges at have en effekt. En af de forandringer, hun selv tillægger betydning under behandlingsforløbet, er netop, at hun pludselig ser på sin sygdom på en ny måde:

Det revolutionerende var at få vendt billedet af de her kræftceller, som skulle bekæmpes, og som blev fuldstændig grønne og blå i hovederne og lå og brækkede sig, det billede har jeg haft blandt andet med kemoterapien, at få vendt den til, at de ville kommunikere noget til mig og var sådan lidt: 'Nå, men var det bare det?!' Og så har vi talt om, at hvis du har en konflikt i en hvilken som helst henseende, og hver part står og bekriger hinanden, så er der en konfliktoptrapning. Og her var det ligesom, man gik i dialog, og det er meget konfliktløsning. De der kræftceller begyndte også at glide ud og blive til sæbebobler, der bare blev puffet ud, i stedet for det her voldsomme dramatiske billede af, at de skulle kvæles, og det synes jeg var enormt fedt.

Heidis tilgang til reiki-healing er udtryk for en magisk praksis, hvor hun prøver lykken for at se, om der er noget, der hjælper mod kræften. Indledningsvis er hendes forventning til behandlingen præget af skepsis, illustreret ved de billeder, der tyder på, at healing er en meget fremmedartet praksis. Alligevel giver hendes åbenhed plads til at etablere en tillid til en behandlingsform, der forklarer sygdom ud fra en anden forståelse end hendes egen. Under behandlingsforløbet befinder 
hun sig i en ligeværdig og fortolkende dialog med healeren omkring de erfaringer, hun gør sig undervejs. Derfra finder de i fællesskab frem til, hvordan sygdommen skal forstås som en del af hendes liv. Gennem denne proces sker der også en gradvis overtagelse af healerens forklaringer og begreber. Det bevirker samtidig, at hun ændrer sin forståelse af sit problem. Selv om hendes intention med ritualet eller behandlingen har været rettet mod noget specifikt, nemlig hjælp til at blive rask, så drejer det sig nu i højere grad om at være i balance og kunne tackle de udfordringer, der kommer. Ved at ændre kursen en smule vil reiki-healing også have den efterspurgte effekt som en magisk praksis. Virkningen, som Heidi fortolker som den effektive del af ritualet, bliver, at hun ser på sygdommen på en ny og mere forsonende måde. Altså, at hun forholder sig anderledes til det at have kræft. Det er et kendetegn ved den religiøse coping, hvor det er oplevelsen af at finde en mening med tingene, der er central.

\section{Reiki-healing set som religiøs coping}

Som kræftramt mister man noget af sit liv. Flere aspekter af tilværelsen bliver besværliggjort efter sygdommens udbrud, og personen bliver eksistentielt udfordret ved udsigten til at dø. Visse forskere mener, at den mest hensigtsmæssige måde at håndtere de eksistentielle udfordringer på er gennem religiøs coping (Musick et al. 1998; Grosseholtforth et al. 1996). Copingbegrebet, der har vundet indpas inden for flere fagdiscipliner, hører oprindelig til inden for stressforskningen. Her bliver begrebet brugt til at beskrive de fysiologiske aspekter, der optræder, når mennesker befinder sig i under stress (Zachariae \& Mehlsen 2004). Coping defineres i denne sammenhæng som en kognitiv og adfærdsmæssig bestræbelse på at mestre såvel ydre som indre krav, der vurderes at kunne overskride personens kapacitet. Coping betragtes som et forsøg på at reducere og tåle stress - og genoprette ligevægt. Begrebet er blevet overtaget af den tidlige kognitive psykologi til at beskrive de handlingsstrategier, mennesket benytter sig af $\mathrm{i}$ belastende livssituationer (Lazarus \& Folkman 1984). Ud fra dette er der opstået en religionspsykologisk interesse for de specielle copingstrategier, der er af religiøs karakter. Det kan for eksempel være at bede eller meditere, når man er i en vanskelig situation. Eller ved at gå til reiki-healing som kræftramt.

Religiøs coping er en måde at håndtere belastende situationer på ved at skabe mening med dem. Det sker ved at trække på en religiøs eller spirituel forståelsesramme (Pargament 2001; Ahmadi 2003). Ved reiki-healingen optræder coping som en måde at komme overens med sygdommen på eller de andre udfordringer, man har, gennem meningsdannelsen. Den proces kan blive synlig under den gensidige fortolkning, der finder sted under samtalen. Her tilpasser healeren som 
nævnt sine udsagn deltagerens forståelse og engagement. Men deltageren har også mulighed for at ændre sin forståelse af tingene i dette forløb og give mening til de kropslige fornemmelser eller følelser, som personen er kommet i kontakt med i forbindelse med behandlingsforløbet.

Empirien fra forskningsprojektet peger på, at det gør en forskel i forhold til coping, hvilken indstilling man har til reiki-healing som behandlingsform. Det viste sig, at det at anvende reiki-healing som en måde at håndtere sygdommen på, eller cope med den, var mere udtalt blandt deltagere, der fra starten forholdt sig meget åbent til behandlingen, enten fordi de havde stiftet bekendtskab med healing tidligere, eller de var i færd med at genopfriske eller opbygge en relation til alternativ behandling. Der kan også være tale om, at de har en beslægtet form for spirituel praksis og derfor tilslutter sig den forståelse, som healeren arbejder ud fra.

Charlotte er et eksempel på denne tilgang. Hun er et sted i 40'erne og har et tilbagefald med brystkræft. Så det er anden gang inden for en kort årrække, at hun har kræft. Hun er uddannet som sygeplejerske. Derfor er hun vant til at arbejde ud fra den biomedicinske tilgang til sygdomme. Hun har en religiøs eller spirituel indstilling til livet, der blev vakt, første gang hun havde brystkræft. Hun beskriver, hvordan hun havde det under sit forrige sygdomsforløb:

Jeg kan huske første gang, hvor jeg var syg, hvor jeg faktisk fik det sådan en periode, at jeg græd og græd og græd. Det var ikke, fordi jeg var ked af det, men jeg havde bare sådan en kærlighed til livet. Det er det eneste, der er i verden, der er ikke andet. [...] Jeg blev skideforskrækket over det på mange måder. Jeg kan huske, jeg tænkte, jeg må ud og snakke med den præst ude på Herlev, han kan nok forstå det, og så gjorde jeg det ikke alligevel. [...] Jeg kan huske, jeg følte mig fuldstændig alene med det og blev skidebange for at være ved at blive religiøs på en eller anden måde, og det ville jeg i hvert fald ikke være. Så jeg undertrykte det.

Hun beskriver de følelser, som kræften fremkalder, som noget, der udfordrer hende, og som hun har svært ved at håndtere selv. Hun oplever at have brug for støtte, hvilket viser sig som et behov for at blive mødt af en, der kan tematisere hendes religiøse følelser.

Hvorfor skulle man ikke have nogen, der støtter en i det undervejs, når det pludselig kommer til en på nogle andre måder? Netop fordi man er blevet syg, så tror jeg, man har brug for det. Jeg havde brug for det første gang, det har jeg virkelig tænkt over, men det havde jeg ikke dengang, jeg blev skideforskrækket over det. Jeg havde ikke en præst, der kunne hjælpe mig eller healer eller et eller andet, der kunne sige til mig: Jamen, bare tag det roligt og giv dig hen til det!

Kvinden vælger under sit første behandlingsforløb at lægge afstand til de religiøse følelser, fordi det i hendes opvækst har været ilde set at være kristen, og det umid- 
delbart er den form for religiøsitet, hun relaterer dem til. Hun finder efter det første kræftforløb frem til en spirituel praksis ved at udøve en meditationsform kaldet „The Work“. Her indarbejder hun en teknik til at undersøge sine tanker for at se anderledes på tilværelsen. I forbindelse med sit andet kræftudbrud og en smertefuld skilsmisse tænker hun, at hun må se mere på de temaer, der dukker op. Hun anvender reiki-healing som en støtte til at få sat sin sygdom ind i en forståelsesramme, som giver mening i forhold til hendes livssituation.

Det at modtage reiki-healing leder hende til en ny forståelse af livet, som rækker ud over døden. I hendes behandlingsforløb er hun flere gange i kontakt med sin krop på en anden måde, end hun er vant til. Det beskriver hun således:

Jeg har haft sådan en fornemmelse af bare at være, altså, at kroppen ligesom ikke var kroppen, men bare noget energi, som gik igennem mig [...] og bare flød frem og tilbage og på den måde dannede kroppen, ikke?

Den kropsfornemmelse minder hun sig selv om imellem behandlingerne, og senere får hun en erkendelse, som hun refererer til som noget afgørende:

Jeg ved ikke, om der lyder åndssvagt, men jeg fik den forståelse, at det liv [...] det vil altid være der til den dag, jeg dør, og så bliver det til noget andet liv. Men uanset hvor syg jeg er, eller hvis jeg nu bliver gammel og totalt nedslidt, så er det den samme slags liv, der er der. Det er lige præcis det samme, der er i alle sammen, også en lille baby, det er hverken mere eller mindre, forstår du, hvad jeg mener? Så det var meget fredfyldt på en måde at se det. At sådan er det, indtil man dør. At uanset hvornår man dør, så er det liv, indtil man dør. [...] Det kan man godt sige: Man lever, indtil man dør.

Hendes tilværelse som enlig mor under kemobehandling og med en nylig skilsmisse i bagagen sættes i perspektiv med denne erkendelse af, at der er liv trods alle udfordringerne. Og at livet bliver til noget andet liv, den dag hun dør. Ud over at være en erkendelse, hun gør sig under en reiki-healing, er det også en måde at forholde sig til, at hun måske snart skal dø. Det betydningsfulde ved oplevelsen er, at hun føler, at der er liv, indtil man dør. Det er en begivenhed, hun vender tilbage til. Den får særlig betydning, ved at den er udsprunget af en kropsligt funderet oplevelse af energi, der for hende er lige så virkelig som ord eller tanker. Oplevelsen har dermed en særlig virkelighedskarakter for hende, som fænomenologien peger på, at der er tale om ved kropsliggjorte erfaringer (Merleau-Ponty 1965). Derved bliver det, der foregik under reiki-behandlingen, til en erfaring, hun tager med ud af behandlingslokalet og anvender til at håndtere de eksistentielle overvejelser, som dukker op i forbindelse med hendes sygdomsforløb. På denne måde ser vi tydeligt at hun har anvendt reiki-healing som religiøs coping. 


\section{Konklusion}

Som kræftramt trækker man på forskellige strategier, der har det sigte at minimere ængstelse og forbedre tilværelsen. At benytte sig af reiki-healing er en strategi, der kan anvendes for at opnå en fysisk eller psykisk bedring. Det er i artiklen beskrevet som en magisk praksis, hvor det magiske ved handlingen består i, at man tillægger et andet menneske (eller en genstand) en magisk agens. Men at benytte sig af reiki-healing kan også være en længsel efter at forstå den livssituation, man er havnet i. I så fald anvendes reiki-healing til at skabe mening og identitet i en svær tid. Den finder sted som en kropsligt funderet praksis, der samtidig tilbyder deltageren at etablere eller bekræfte det virkelighedsbillede, som healeren tilslutter sig. Accepteres dette virkelighedsbillede, får personen mulighed for at se sin sygdom som del af en meningsfuld sammenhæng. Det at tro på, at der er en mening med den situation, man befinder sig i, styrker ens evne til at håndtere de udfordringer, man står over for. En sådan tilgang til reiki-healing er at sammenligne med religiøse copingstrategier som for eksempel bøn eller meditation, der ligeledes anvendes for at hente styrke, og som samtidig bekræfter det virkelighedsbillede, man er tilhænger af.

Artiklen konkluderer, at når kræftramte bruger reiki-healing, kan det ses som en magisk praksis, der indeholder elementer af religiøs coping. Magisk praksis optræder derfor som et overordnet begreb, mens religiøs coping kun gør sig gældende, når deltageren tolker sin sygdom ind i den forståelsesramme, som reiki-healing tilbyder den kræftramte. Men fælles for begge tilgange er, at de er et forsøg på at fastholde en indflydelse på egen tilværelse og krop, som ellers ligger uden for ens rækkevidde.

Men fra at betegne brugen af reiki-healing som en magisk praksis til at kalde brugere af reiki-healing for religiøse eller magikere, er der et spring. Måske er der tale om, at de forskellige former for virkelighedsbilleder, man trækker på, er tæt tilknyttet de forskellige behandlingsformer, man benytter sig af. Derfor opfatter de fleste kræftramte det ikke nødvendigvis som en personlig konflikt, at lægen opererer med et naturvidenskabeligt verdensbillede og herunder en biomedicinsk opfattelse af kroppen, mens healeren orienterer sig ud fra en holistisk og energibaseret forståelse af mennesket. Der er fra den kræftramtes synsvinkel behov for flere tilgange til sygdommen. Derfor opleves behandlingsformerne måske ikke som modstridende af den kræftramte, men kun af udøverne, for hvem virkelighedens karakter er afgørende for deres behandlings berettigelse.

At modtage reiki-healing giver de kræftramte mulighed for at se deres livssituation i en særlig menings- og forståelsesramme, som de kan fortolke og bearbejde deres tilværelse ud fra. På denne måde kan reiki-healing blive et senmoderne bidrag til det, der er en af religionens opgaver, nemlig at finde mening med lidelse. 


\section{Noter}

1. Projektet er et kvalitativt studie finansieret af Kræftens Bekæmpelse. Det er udført af cand.psych. Jakob Skov Knudsen og undertegnede under ledelse af professor Bo Jacobsen i tilknytning til forskningsnetværket KUFAB på Københavns Universitet.

2. „Clairvoyance“ betyder klarsyn og bruges som betegnelse for de mennesker, der tillægges ekstra sensoriske evner som at kunne se et menneskes udstråling, kaldet ,aura“, fremtiden, afdøde eller spirituelle væsner.

3. Healeren, der også er uddannet sanger, mener, at lydhealing får cellerne til at komme tilbage til deres rette svingningsgrad. Kræftceller er kommet ud af svingning og opfører sig derfor anormalt.

4. Misteltenbehandling består af en direkte injektion af et planteudtræk fra misteltenen. Dette menes at få kræftknuden til at svinde. Der er ingen videnskabelig evidens for behandlingen.

Nøgleord: Healing, reiki, magi, religiøs coping, helbredelsesritual, kræft.

\section{Litteratur}

Ahlin, Lars

2007 Krop, sind - eller ånd? Alternative behandlere og spiritualitet i Danmark.

Højbjerg: Univers.

Ahmadi, Fereshteh

2006 Religion and Spirituality in Coping. The example of cancer patients in Sweden.

Stockholm: Uppsala University Press.

Antonovski, Aron

$2000 \quad$ Helbredets mysterier. København: Hans Reitzels Forlag.

Damkier, Anette

$2000 \quad$ Kræftpatienters brug af alternativ behandling. Ph.d.-afhandling. Odense: Syddansk Universitet, Det Sundhedsvidenskabelige Fakultet.

Doi, Hiroshi

2003 Reiki: En vej til selvudvikling og healing. Den traditionelle japanske reiki-metode tilpasset nutiden. Valby: Borgen.

Eisenberg, David Miles et al.

1998 Trends in Alternative Medicine Use in the United States, 1990-1997: Results of a follow-up national survey. JAMA 280(18):1569-75.

Grosseholtforth, Martin et al.

1996 Medical Illness, Religion, Health Control and Depression of Institutionalized Medically Ill Veterans in Long-Term Care. International Journal of Geriatric Psychiatry, 11(7):613-20.

Humphrey, Caroline \& James Laidlaw

1994 The Archetypal Actions of Ritual: An essay on ritual as action illustrated by the Jain worship. Oxford: Oxford University Press. 
Jacobsen, Bo

2000 Eksistenspsykologi. En introduktion. København: Hans Reitzels Forlag.

Jacobsen, Bo et al.

1998 Kræft og eksistens: Om at leve med kræft. København: Dansk Psykologisk Forlag.

Lazarus, Richard S. \& Susan Folkman

1984 Stress, Appraisal and Coping. New York: Springer Publishing Company Inc.

Merleau-Pony, Maurice

1965 Phenomenology of Perception. London: Routledge.

Musick, Marc A. et al.

1998 Religious Activity and Depression among Community-Dwelling Elderly Persons with Cancer: The moderating effect of race. Journals of Gerontology (Series B). Psychological Sciences and Social Sciences 53(4):218-27.

Ostenfeld-Rosenthal, Ann

2005 Healernes Univers. Spirituel healing i Danmark: Opfattelser af sygdom og helbredelse - et antropologisk pilotprojekt. Århus: Århus Universitet og Århus Sygehus.

2007 Symbolsk healing 'embodied'. Krop, mening og spiritualitet i danske helbredelsesritualer. Tidsskrift for Forskning i Sygdom og Samfund 6:129-50.

Pargament, Kenneth

2001 The Psychology of Religion and Coping. Theory, research and practice. New York: Guildford Press.

Rubow, Cecilie

2000 Hverdagens teologi. Folkereligiøsitet i danske verdner. København: Forlaget Anis

Sørensen, Jesper

2008 A Cognitive Theory of Magic. Plymouth: Altamira Press.

Zachariae, Bobby \& Mimi Y. Mehlsen

$2004 \quad$ Kræftens psykologi: Psykologiske og sociale aspekter ved kræft.

København: Hans Reitzels Forlag. 
